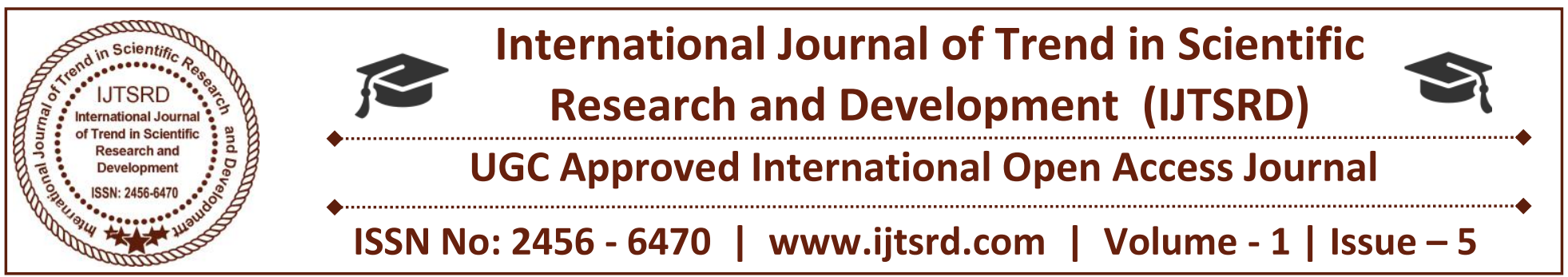

\title{
Capital Structure and Profitability: A Correlation Study of Selected Pharmaceutical Companies of India
}

\author{
Dhamelia Hardita \\ P.G.Scholar (Commerce), \\ S.D.R.B Mahila Home Science and Lt M.J.Kundaliya \\ Eng. Med. Mahila Commerce College, Rajkot
}

\begin{abstract}
Capital structure plays an important role in for the profitability of the company but there are many other factors that affect the profit of the company (i.e. management, pricing policy, Advertisement etc.) .The research was undertaken to know the relationship between capital structure and profitability of 4 listed companies of pharmaceutical sector. The data has been analyzed by using descriptive statistics and correlation analysis to know the relation between considered variables. It shows that negative relation between the debt equity and other variables like net profit, capital employed and return on net worth but the relation is no significantly negative.
\end{abstract}

Keywords: Profitability, Capital Employed, DebtEquity, Return on Net Worth

\section{Introduction}

This study focuses to know and understand the relation between capital structure and profitability of different Pharmaceutical companies. Profitability is the profit earning capacity which is crucial factor contributing to the survival of the firms. Profitability can be measured in terms of profit shown as a percentage of sales know as profit margin. The concept of capital structure is generally interpreted as the combination of Debt and Equity that makes the total capital of the firm. The term capital structure mainly includes a combination of equity shares, preference shares and long term debts. The company may fail or suffer from losses if capital structure and utilization of funds is not planned in proper way. Proper utilizatio1azn of funds helps to achieve the goals of the company and can easily adapt the changing conditions. Company's capital structure largely depends on company-specific factors such as the probability of bankruptcy, profitability, quality and structure of assets. Capital structure refers to a set of rules and incentives by which management of a company is directed and controlled. There are independent variables like debt to equity and long term debt to equity which forms the capital structure of the company. Capital structure plays a vital role in profitability of any company but there are many other factors accept capital structure that affects the profit of the company.

\section{Review of related Literature}

Acquash, P; Freeman, E; and Ellis, E (2017) has studied the relationship between capital structure and profitability of oil marketing companies. The researchers have undertaken the study of two listed firms of Ghana Stock Exchange. The researcher have considered various factors for this study like firms capital structure, short term debt to total capital, long term debt to total capital, return on assets, return on equity and net profit margin. They have analyzed the data using multiple regressions. The main outcome of their study is that it demonstrates that increments in short term debts and long term obligation influences the execution of oil marketing companies. The results 
of analysis shows that short term debt to total capital, long term debt capital and total debt to total capital are independent variables in comparison with return on assets, return on equity and net profit margin as dependent variables concludes that capital structure using leverage ratio have negative effect on profitability as measured on return on assets, return on equity and net profit margin of oil marketing companies.

Khalid, A; Khursheed, A and Mouh-i-Din, S (2013) have studied the impact of capital structure on profitability of listed companies. They have taken into consideration the data of Automobile Industry. The main objective of researchers was to know the relationship between the capital structure and profitability of the firms. They have considered many different ratios in their study and have found correlation matrix for capital structure and profitability of the firms. They have included different ratios like Debt to Equity, debt to assets, gross profit ratio, net profit ratio, operating profit, return on capital employed. They found in their study that debt to equity ratio in negatively correlated to profitability ratio. Debt to assets ratio and interest coverage ratio and positively and significantly correlated with the profitability ratio. Thus capital structure does have statistically significant impact on profitability of firms.

Velnampy, T and Niresh, J (2012) have studied the relationship between capital Structure and profitability. They have studied the variables of 10 listed Srilankan banks. The researchers have considered various ratios to know relation between capital structure and profitability. It includes Debt to equity, debt to total funds, net profit ratio, return on capital employed, return on equity and net interest margin. In this research the researcher found that there is negative relation between capital structure and profitability except the reltaion between debt to equity and return on equity.

\section{Objectives of Research}

Following are the objectives of present research paper:
1) To understand the capital structure of the Pharmaceutical Companies.

2) To know the relationship between capital structure and profitability of the company.

\section{Hypothesis of the study}

The following Hypothesis were formulated for the study

$>\mathrm{H}_{0}$-There is a negative relationship between Debt to Equity and Net Profit.

$>\mathrm{H}_{0}$-There is a negative relationship between Debt to Equity and Return on Capital Employed

$>\mathrm{H}_{0}$-There is a negative relationship between Debt to Equity and Return on Net Worth / Equity

$>\mathrm{H}_{0}$-There is a $\mathrm{t}$ negative relationship between Debt to Total Funds and Net Profit.

$>\mathrm{H}_{0}$-There is a negative relationship between Debt to Total Funds and return on Capital Employed.

$>\mathrm{H}_{0}$-There is a negative relationship between Debt to Total Funds and Return on Net Worth / Equity

\section{Research Methodology}

In order to carry out the research work properly and systematically, it is necessary to prepare a research methodology first. In the present research paper, following research methodology is used.

\section{Title of the study}

Title of study is as under:

"Capital Structure and Profitability: A Correlation Study of Selected Pharmaceutical companies of India”

\section{Sample size}

The study is undertaken by considering the data of different companies associated with Pharmaceutical sector. The researcher has taken into consideration 4 different companies associated with pharmaceutical sector. The study includes Torrent Pharmaceuticals, Cadila Healthcare, Ajanta Pharma and IPCA Laboratories. 


\section{Sample Profile}

\begin{tabular}{|c|c|c|c|c|}
\hline & TORRENT & CADILA & AJANTA & Ipca \\
\hline Listed As & $\begin{array}{l}\text { BSE: } 500420 \\
\text { NSE: } \\
\text { TORNTPHARM } \\
\text { ISIN: } \\
\text { INE685A01028 } \\
\text { SECTOR: } \\
\text { Pharmaceuticals }\end{array}$ & $\begin{array}{l}\text { BSE: } 532321 \\
\text { NSE: } \\
\text { CADILAHC } \\
\text { ISIN: } \\
\text { INE010B01027 } \\
\text { SECTOR: } \\
\text { Pharmaceuticals }\end{array}$ & $\begin{array}{l}\text { BSE: } 532331 \\
\text { NSE: } \\
\text { AJANTPHARM } \\
\text { ISIN: } \\
\text { INE031B01049 } \\
\text { SECTOR: } \\
\text { Pharmaceuticals }\end{array}$ & $\begin{array}{l}\text { BSE: } 524494 \\
\text { NSE: } \\
\text { IPCALAB } \\
\text { ISIN: } \\
\text { INE571A01020 } \\
\text { SECTOR: } \\
\text { Pharmaceuticals }\end{array}$ \\
\hline Founded On & 1959 & 1952 & 1973 & 1949 \\
\hline Headquarters & Ahmedabad, India & Ahmedabad, India & Mumbai, India & Mumbai, India \\
\hline $\begin{array}{l}\text { Main } \\
\text { Members }\end{array}$ & $\begin{array}{l}\text { Sudhir Mehta, } \\
\text { Samir Mehta }\end{array}$ & Ramanbhai Patel & $\begin{array}{l}\text { Yogesh Agrawal, } \\
\text { Rajesh Agrawal }\end{array}$ & $\begin{array}{l}\text { K.B. Mehla } \\
\text { Dr. N.S. Tibrawala }\end{array}$ \\
\hline Revenue & INR 66 billion & INR 54.7 Billion & INR 17.05 Billion & INR 15.59 Billion \\
\hline $\begin{array}{l}\text { Employees } \\
\text { working }\end{array}$ & 8600 & 13180 & $6,500+$ & 12000 \\
\hline
\end{tabular}

\section{Method of Data Collection}

The researcher has used secondary data for the analysis. The details of different ratios are taken fromwww.moneycontrol.com dated on $1^{\text {st }}$ July 2017. The details have been collected from the financial statement and ratios given by the company. The researcher has considered the data of last 4 years for the study.

\section{Tools and Techniques}

The researcher has used Descriptive Statistics as well as inferential test to analyse the data to know the relationship between profitability and capital structure of the company. Descriptive Statistics analysis helps to know the mean and standard deviation. Inferential test statistics helps to draw conclusions from the data and helps to test the hypothesis considered by the researcher. It includes the Correlation Analysis.

\section{Limitation of Present Research}

1) The method of data collection is secondary so the data which is available is not reliable.

2) The data has been collected for 4 years only so the result is not applicable for coming years.

3) The outcomes are only available for the above companies and not the other companies 
International Journal of Trend in Scientific Research and Development (IJTSRD) ISSN: 2456-6470

Analysis and Interpretation

Table - 1

A Table Showing Descriptive Statistics

\begin{tabular}{|c|c|c|c|c|c|}
\hline & $\mathbf{N}$ & Minimum & Maximum & Mean & $\begin{array}{c}\text { Std. } \\
\text { Deviation }\end{array}$ \\
\hline COMPANY & 16 & 1 & 4 & 2.50 & 1.155 \\
\hline NET PROFIT RATIO & 16 & 3.24 & 32.48 & 18.7694 & 7.73581 \\
\hline RETURN ON CAPITAL EMPLOYED & 16 & 4.76 & 48.90 & 26.5356 & 11.10900 \\
\hline RETURN ON NETWORTH & 16 & 3.96 & 47.83 & 27.8444 & 11.26566 \\
\hline DEBT/ EQUITY RATIO & 16 & .05 & .84 & .3350 & .19456 \\
\hline LONG TERM DEBT/ EQUITY & 16 & .01 & .81 & .2363 & .19363 \\
\hline Valid N (list wise) & 16 & & & & \\
\hline
\end{tabular}

Descriptive statistics (Table 1) shows that no of companies and different ratios considered by the researcher in their studies. It shows the minimum and maximum values of different ratios and the mean and standard deviation of different ratios. Here it shows that long term debt/ equity ratio shows lowest values as compared to other ratios considered in the study.

Table 2

A Table showing Correlation Analysis

\begin{tabular}{|c|c|c|c|c|c|c|}
\hline & & $\begin{array}{c}\text { NET } \\
\text { PROFIT } \\
\text { RATIO }\end{array}$ & $\begin{array}{l}\text { RETURN ON } \\
\text { CAPITAL } \\
\text { EMPLOYED }\end{array}$ & $\begin{array}{l}\text { RETURN ON } \\
\text { NETWORTH }\end{array}$ & $\begin{array}{c}\text { DEBT } \\
\text { EQUITY } \\
\text { RATIO }\end{array}$ & $\begin{array}{c}\text { LONG TERM } \\
\text { DEBT } \\
\text { EQUITY }\end{array}$ \\
\hline \multirow[t]{3}{*}{$\begin{array}{l}\text { NET PROFIT } \\
\text { RATIO }\end{array}$} & $\begin{array}{l}\text { Pearson } \\
\text { Correlation }\end{array}$ & 1 & $.855^{* *}$ & $.857^{* *}$ & -.136 & -.016 \\
\hline & Sig. (2-tailed) & & .000 & .000 & .615 & .953 \\
\hline & $\mathrm{N}$ & 16 & 16 & 16 & 16 & 16 \\
\hline \multirow{3}{*}{$\begin{array}{l}\text { RETURN ON } \\
\text { CAPITAL } \\
\text { EMPLOYED }\end{array}$} & $\begin{array}{l}\text { Pearson } \\
\text { Correlation }\end{array}$ & $.855^{* *}$ & 1 & $.966^{* *}$ & -.297 & -.114 \\
\hline & Sig. (2-tailed) & .000 & & .000 & .263 & .673 \\
\hline & $\mathrm{N}$ & 16 & 16 & 16 & 16 & 16 \\
\hline \multirow[t]{3}{*}{$\begin{array}{l}\text { RETURN ON } \\
\text { NETWORTH }\end{array}$} & $\begin{array}{l}\text { Pearson } \\
\text { Correlation }\end{array}$ & $.857^{* *}$ & $.966^{* *}$ & 1 & -.237 & -.088 \\
\hline & Sig. (2-tailed) & .000 & .000 & & .376 & .747 \\
\hline & $\mathrm{N}$ & 16 & 16 & 16 & 16 & 16 \\
\hline \multirow{3}{*}{$\begin{array}{l}\text { DEBT } \\
\text { EQUITY } \\
\text { RATIO }\end{array}$} & $\begin{array}{l}\text { Pearson } \\
\text { Correlation }\end{array}$ & -.136 & -.297 & -.237 & 1 & $.930^{* * *}$ \\
\hline & Sig. (2-tailed) & .615 & .263 & .376 & & .000 \\
\hline & $\mathrm{N}$ & 16 & 16 & 16 & 16 & 16 \\
\hline \multirow{3}{*}{$\begin{array}{l}\text { LONG } \\
\text { TERM DEBT } \\
\text { EQUITY }\end{array}$} & $\begin{array}{l}\text { Pearson } \\
\text { Correlation }\end{array}$ & -.016 & -.114 & -.088 & $.930^{* *}$ & 1 \\
\hline & Sig. (2-tailed) & .953 & .673 & .747 & .000 & \\
\hline & $\mathrm{N}$ & 16 & 16 & 16 & 16 & 16 \\
\hline
\end{tabular}

** Correlation - significant at the 0.01 level (2-tailed)

Table 2 shows the relationship between various independent and dependent variables considered in the study it shows that there is negative relation between all independent and dependent variables. 
Table 3

Showing result of Hypothesis Test

\begin{tabular}{|c|c|c|c|}
\hline No & Hypothesis & Results & Tools \\
\hline $\mathbf{H}_{\mathbf{0}}$ & $\begin{array}{l}\text { There is a negative relationship between Debt to Equity and Net } \\
\text { Profit. }\end{array}$ & Accepted & Correlation \\
\hline $\mathbf{H}_{\mathbf{0}}$ & $\begin{array}{l}\text { There is a negative relationship between Debt to Equity and Return } \\
\text { on Capital Employed }\end{array}$ & Accepted & Correlation \\
\hline $\mathbf{H}_{\mathbf{0}}$ & $\begin{array}{l}\text { There is a negative relationship between Debt to Equity and Return } \\
\text { on Net Worth / Equity }\end{array}$ & Accepted & Correlation \\
\hline $\mathbf{H}_{\mathbf{0}}$ & $\begin{array}{l}\text { There is a negative relationship between Debt to Total Funds and } \\
\text { Net Profit. }\end{array}$ & Accepted & Correlation \\
\hline $\mathbf{H}_{\mathbf{0}}$ & $\begin{array}{l}\text { There is a negative relationship between Debt to Total Funds and } \\
\text { return on Capital Employed. }\end{array}$ & Accepted & Correlation \\
\hline $\mathbf{H}_{\mathbf{0}}$ & $\begin{array}{l}\text { There is a negative relationship between Debt to Total Funds and } \\
\text { Return on Net Worth / Equity }\end{array}$ & Accepted & Correlation \\
\hline
\end{tabular}

\section{Major Findings}

1) From the present study researcher has found that there is negative relation between Debt Equity ratio and Net Profit Ratio but statistical evidences shows that it is not significantly negative.

2) From the present study researcher has found that there is negative relation between Debt Equity ratio and Capital Employed but statistical evidences shows that it is not significantly negative.

3) From the present study researcher has found that there is negative relation between Debt Equity ratio and Return on Net Worth/ Equity but statistical evidences shows that it is not significantly negative.

\section{Conclusion}

From the present research paper we can conclude that profitability of any company does not only dependent on Capital structure of the company there are many other factors that affect the profit of the company. There is negative relation between Debt equity and Net Profit Ratio, Capital Employed and Return on Net Worth but we can't say there is significantly negative relation among them.

\section{REFERENCES}

1) Acquash, P; Freeman, E and Ellis, E (2017) "Relationship between Capital Structure and Profitability of Oil Marketing Companies (OMCs)" International Journal of Multidisciplinary Research and Development Vol. 4 (3) March 2017, PP110-116
2) Kajananthan, $\mathbf{R}$ (2012) "Effect of Corporate Governance on Capital Structure Case of the Srilankan Listed Manufacturing Companies" International Refereed Research Journal Vol. 3 (4) October, 2016, PP 63-71

3) Kajananthan, $R$ and Nimalthasan ,P (2013) "Capital Structure and its Impact on firm Performance, A study on Sri Lankan Listed Manufacturing Companies" Merit Research Journal of Business and management Vol. 1(22) December, 2013, PP 37-44

4) Khalid A;Khursheed A and Mouh-i-Din, S (2013) "Impact of Capital Structure on Profitability of Listed Companies (Evidence from India)" The USV Annals of Economics and Public Administration, Vol. 13 (17) 2013, PP 183-191

5) Movalia, N (2015) "A study on Capital Structure Analysis and Profitability of Indian Tyres Industry" Pacific Business Review International, Vol. 8(3) September, 2015, PP 78-82

6) Tailab, M (2014)“'The Effect on Capital Structure Analysis and Profitability of Energy American Firms" International Journal of Business and Management Invention Vol. 3(2) September, 2014, PP 54-61

7) Velnampy, T and Niresh, A "The Relationship between Capital Structure and Profitability", Global Journal of Management and Business Research Vol. 12 (13) 2012, PP 65-73 